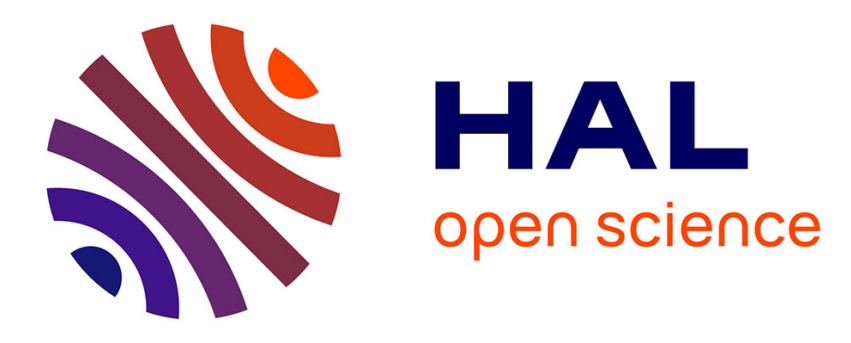

\title{
Geographic distance and remittances in Romania: Out of sight, out of mind?
}

José de Sousa, Laetitia Duval

\section{To cite this version:}

José de Sousa, Laetitia Duval. Geographic distance and remittances in Romania: Out of sight, out of mind?. International Economics/Economie Internationale, 2010, 121, pp.81-97. 10.1016/S21107017(13)60009-8 . hal-01221463

\section{HAL Id: hal-01221463 \\ https://hal.science/hal-01221463}

Submitted on 28 Oct 2015

HAL is a multi-disciplinary open access archive for the deposit and dissemination of scientific research documents, whether they are published or not. The documents may come from teaching and research institutions in France or abroad, or from public or private research centers.
L'archive ouverte pluridisciplinaire HAL, est destinée au dépôt et à la diffusion de documents scientifiques de niveau recherche, publiés ou non, émanant des établissements d'enseignement et de recherche français ou étrangers, des laboratoires publics ou privés. 


\title{
Geographic distance and remittances in Romania: out of sight, out of mind? ${ }^{1}$
}

\author{
José de Sousa*
}

\author{
Laetitia Duval $^{* *}$
}

\section{International Economics 121 (2010)}

\begin{abstract}
We analyse the role of geographic distance for bilateral remittances. We use a new data set on bilateral remittance flows from OECD countries to Romania over the period 20052009. Contrasting with existing literature, we find that remittances increase with distance but in a non-linear way.
\end{abstract}

Keywords: International migration; remittances; bilateral data; Romania.

JEL classification codes: F24, J61, O15.

\footnotetext{
${ }^{1}$ Acknowledgements. We are grateful to the Editor for suggesting us a promising line of research and for his encouragements. We thank also two anonymous referees, Luc Arrondel, Michael Landesman, Olivier Lamotte, El Mouhoub Mouhoud, Jean-François Nivet, Hillel Rapoport, Claudia Senik, Fabien Tripier and FrançoisCharles Wolff for helpful comments and discussions. We benefited from presentations and discussions with seminar participants at AFSE (Paris), INED (Paris), WIIW (Vienna) and Universities of Bologna, Oradéa, Paris 1 and Targoviste. We also thank Valentin Lazea, chief economist at the National Bank of Romania, to have provided us the remittances data and to have answered many questions concerning their construction.

* Corresponding author. CREM, University of Rennes 1 and CES, University of Paris 1 Panthéon-Sorbonne, 106-112 Bd de 1'hôpital, 75013 Paris, France. Email: jdesousa@univ-paris1.fr.

** LEMNA, University of Nantes.
} 


\section{Introduction}

In this paper, we use a new data set on bilateral remittance flows to analyse the impact of geographic distance on remittances. It is now recognized that migration decisions are made in a family context (Borjas, 1999), and that remittances are a central element of familial arrangements (Rapoport and Docquier, 2006). In this context, the migrant's distance from its family (stayed at home) may have an impact on remittances. This impact has not been much explored in the literature. ${ }^{2}$ It appears to be ambiguous. Distance can cause remittances to rise or fall. Remittances might decrease with distance in the three following cases: (1) if remittances contain an altruistic component and "if one admits that altruism is solvable in distance" (Rapoport and Docquier, 2006); (2) if remote migration increases strategic behaviours. Increasing distance from family may reduce the enforcement of any familial arrangement agreed before migration. Among others, distance renders migrant's resources imperfectly observable (Rapoport and Docquier, 2006). Finally (3), remittances may decrease with distance if the latter is assumed to be a proxy for transfer costs (Lueth and Ruiz-Arranz, 2008; Frankel, 2009). ${ }^{3}$

Two arguments can be put forward to understand why remittances might increase with distance. The first argument is related to the type of data we observe. We mainly observe official remittances, transiting through formal channels, such as banks or money transfer companies. Thus, remittances may increase with geographic distance if long-distance migrants tend to remit in a more formal way than short-distance migrants. This is all the more expected if the former return home less frequently. They have fewer opportunities to make transfers in-kind or to carry themselves the money. The second argument is related to the

\footnotetext{
${ }^{2}$ See Adams (2009) and Freund and Spatafora (2008) for recent contributions on the determinants of aggregate remittances in developing countries.

${ }^{3}$ Later on, we will challenge this assumption of a transfer cost effect.
} 
direct costs of emigration (e.g. transporting persons and household goods or obtaining visa) ${ }^{4}$ and the fact that individuals in developing countries face bidding liquidity constraints to emigrate. The literature documents that informal familial arrangements may occur to alleviate such constraints. The family provides implicit loans to finance the costs of emigration. Then, migrants send back money home partly to reimburse costs of emigration (see Johnson and Whitelaw, 1974; Lucas and Stark, 1985; Poirine, 1997; Stark and Lucas, 1988; Ilahi and Jafarey, 1999). As long as the costs of emigration increase with remote destinations (Mayda, 2009), ${ }^{5}$ remittances are expected to increase with the distance to the sending country.

The sign of the impact of distance on remittances is thus an empirical question. To answer this question, we use a new data set of the National Bank of Romania. This data set breaks down inflows of Romanian remittances by sending country. This bilateral dimension allows us to focus on the role of the geographic distance between Romania and the sending countries. Romania is, for various reasons, a relevant receiving country. First, it is a recent country of massive emigration. Second, Romania is currently in the top-10 receiving countries of remittances in the world. Finally, Romania joined the European Union (EU) on January 1, 2007, but is still considered as a middle-income country. Poverty persists and acts as a push factor of migration (see World Bank, 2003).

This paper makes several contributions to the literature. First, we explore the role of geographic distance and find that long-distance migrants tend to remit more than shortdistance migrants. But, this effect tends to be at diminishing rates and specific to some groups of countries. Second, we confirm the significant effect of economic size, as well as financial and labour market factors. Third, using the time series dimension of data, from 2005 to 2009 , we document a negative impact of the recent financial crises on remittances to Romania.

\footnotetext{
${ }^{4}$ Borjas (1999: 1711) also points out two indirect costs: "forgone earnings (for example, the opportunity cost of a post-migration unemployment spell), and psychic costs (for example, the disutility associated with leaving behind family ties and social networks)".

${ }^{5}$ Mayda (2009) shows cogently that, among the variables affecting the costs of emigration, geographic distance appears to be the most important one.
} 
The rest of the paper is as follows. In the next section, we briefly review some stylised facts about the Romanian international migration and remittances. In section 3, we describe our bilateral data set and discuss very recent contributions in relation to the type of data we use. In section 4, we design our empirical model. In section 5, we expose the results. Finally, we conclude in section 6 .

\section{Facts and issues about migration and remittances}

In this section, we review some stylised facts about the Romanian migration and remittances. First, the Romanian transition, at the beginning of the 1990s, triggered a new and large emigration. In 2007, the stock of legal Romanian emigrants reached 1.2 million and $5.7 \%$ of population (Ratha and $\mathrm{Xu}, 2008){ }^{6}$ This emigration follows some specific stages. Second, Romania is currently in the top-10 receiving countries of remittances in the world.

\subsection{A massive emigration}

Since the beginning of transition, Romanian international emigration could be subdivided into three stages (Diminescu, 2003). The first stage (1989-1994) follows the opening of borders. Romanian migrants headed mainly to short-distance country such as Hungary or Serbia. The second stage (1995-2001) extends migration to Western European countries (e.g. Germany, Austria or France), and Mediterranean countries (e.g. Greece, Italy or Spain). This is a mean to face the deterioration of economic and social consequences of transition. For illustration, the unemployment rate rose from 3.0\% in 1991 to over 10\% from 1993 onwards. Moreover, $28.9 \%$ of the Romanian population is living below the national poverty line in 2002 and $10.2 \%$ live in severe poverty (defined as those with insufficient means to purchase a minimum caloric intake each day) (World Bank, 2003: 18). The third stage corresponds to the normalization of Romanian emigration in Europe. From 2002 to 2007, Romanians were

\footnotetext{
${ }^{6}$ Evaluating illegal migration is an issue but stock data are still more reliable than flows. "There is a high turnover among illegal migrants, and many of them tend to be regularised after some time" (Docquier and Rapoport (2009: 4).
} 
allowed to stay without visa in the Schengen area for a maximum of 90 days $^{7}$. After the EU accession in 2007, Romania enjoys the free movement of persons, but still not the free movement of workers. 8

\subsection{A top-10 remittance receiving country}

Remittances to Romania increased from US \$96 million in 2000 to 9.3 billion in 2008. For comparison, they represent $5.5 \%$ of GDP and about $60 \%$ of foreign direct investment inflows. Romania is currently in the top-10 receiving countries of remittances in the world (see Figure $1)$.

Figure 1. Top Remittance-receiving countries, US \$ Billion (2007)

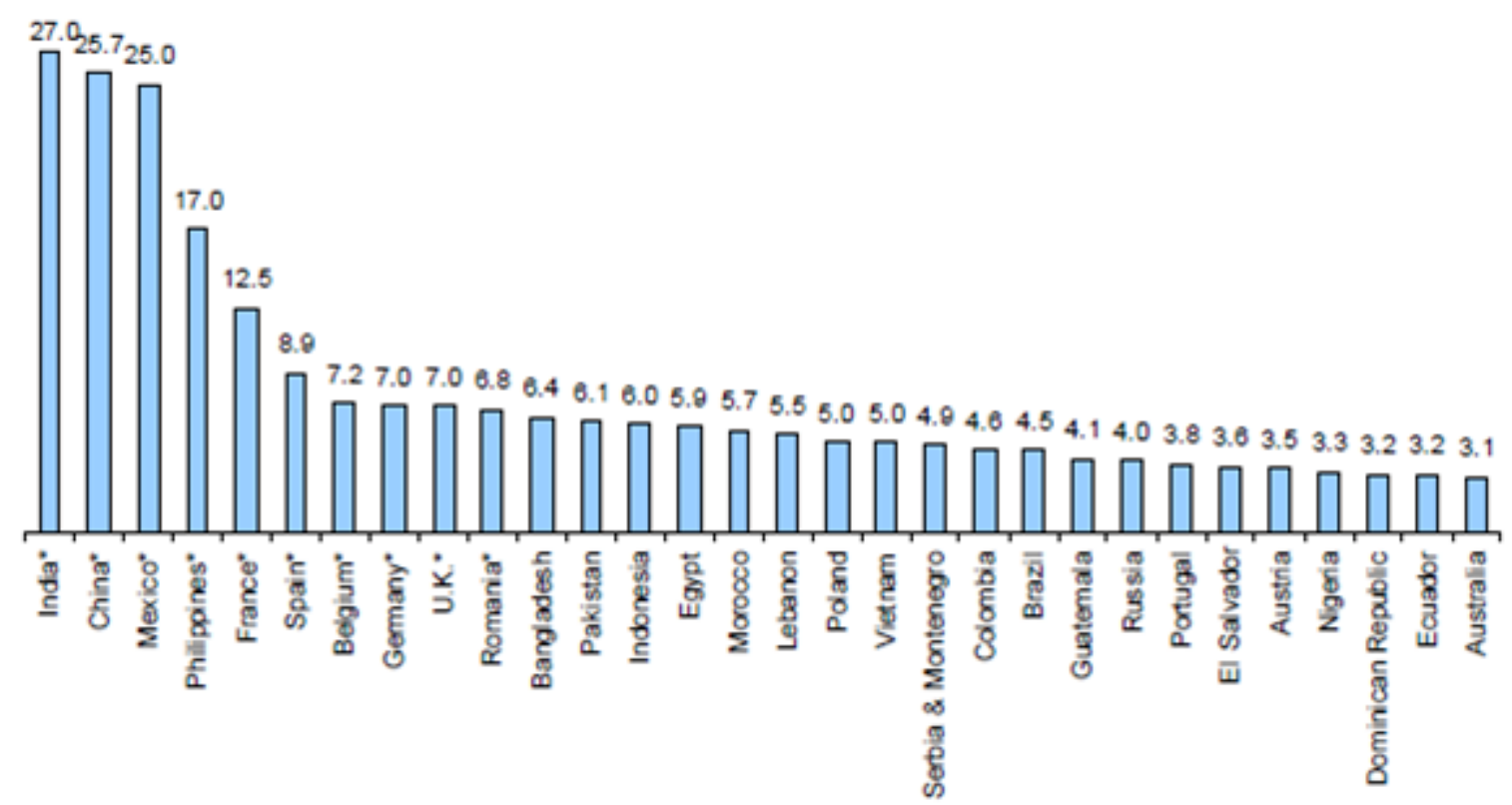

Source: Development Prospects Group, World Bank (2008).

\section{Bilateral data on remittances}

\footnotetext{
${ }^{7}$ The Schengen agreement has been signed in 1995 between Belgium, France, Germany, Luxembourg and the Netherlands. It removed border controls between the participating countries.

${ }^{8}$ All EU-27 members are required to implement Schengen, except Bulgaria, Cyprus, Ireland, the United Kingdom and Romania. Removal of the restrictions on the movement of Romanian workers into the EU is expected from 2012 .
} 
Data on bilateral remittances come from the National Bank of Romania. They are collected via (1) banks reports for amounts received in banks accounts, (2) reports of the money transfer companies such as Western Union and Money Gram and (3) reports of the National Post Office for amounts sent via postal orders. ${ }^{9}$ We identify recorded flows to Romania from 18 sending countries: Austria, Belgium, Canada, Cyprus, Denmark, France, Germany, Greece, Ireland, Israel, Italy, the Netherlands, Portugal, Spain, Switzerland, Turkey, the United Kingdom and the United States. Table 1 reports the main remittance-sending countries in our sample. We also provide their bilateral geographic distance with Romania. The average distance in our sample is about $2450 \mathrm{kms}$. The most remote countries are the United States (7986 kms) and Canada (7422 kms), while Greece $(741 \mathrm{kms})$ and Turkey $(746 \mathrm{kms})$ are the closest.

Table 1. The main remittance sending countries in our sample (2005-2009)

\begin{tabular}{|c|l|l|l|}
\hline & Country & $\begin{array}{l}\text { Remittances to Romania (US \$ } \\
\text { Million) }\end{array}$ & $\begin{array}{l}\text { Distance from Romania } \\
(\mathrm{km})\end{array}$ \\
\hline 1 & Italy & 473.79 & 1139 \\
\hline 2 & Spain & 286.29 & 2477 \\
\hline 3 & United States & 148.81 & 7656 \\
\hline 4 & United Kingdom & 67.32 & 2097 \\
\hline 5 & Germany & 49.56 & 1621 \\
\hline 6 & Greece & 42.59 & 741 \\
\hline 7 & France & 26.06 & 1875 \\
\hline 8 & Austria & 16.73 & 859 \\
\hline 9 & Portugal & 15.48 & 2978 \\
\hline 10 & Ireland & 15.40 & 2541 \\
\hline
\end{tabular}

Note: Average remittances per semester in US \$ million. Geographic distance from capital to capital. Source: Remittance (National Bank of Romania) and distance (CEPII).

Data are quite recent and on a quarterly frequency. Available data cover 2005, 2006, 2007, 2008 and the first three quarters of 2009. Figure 2 provides a simple map on the geography of remittances to Romania over the whole period.

Figure 2. Remittance-sending countries to Romania, US \$ Million (2005-2009)

\footnotetext{
${ }^{9}$ The National Bank of Romania estimates that around 40 per cent of remittances are coming through informal channels.
} 


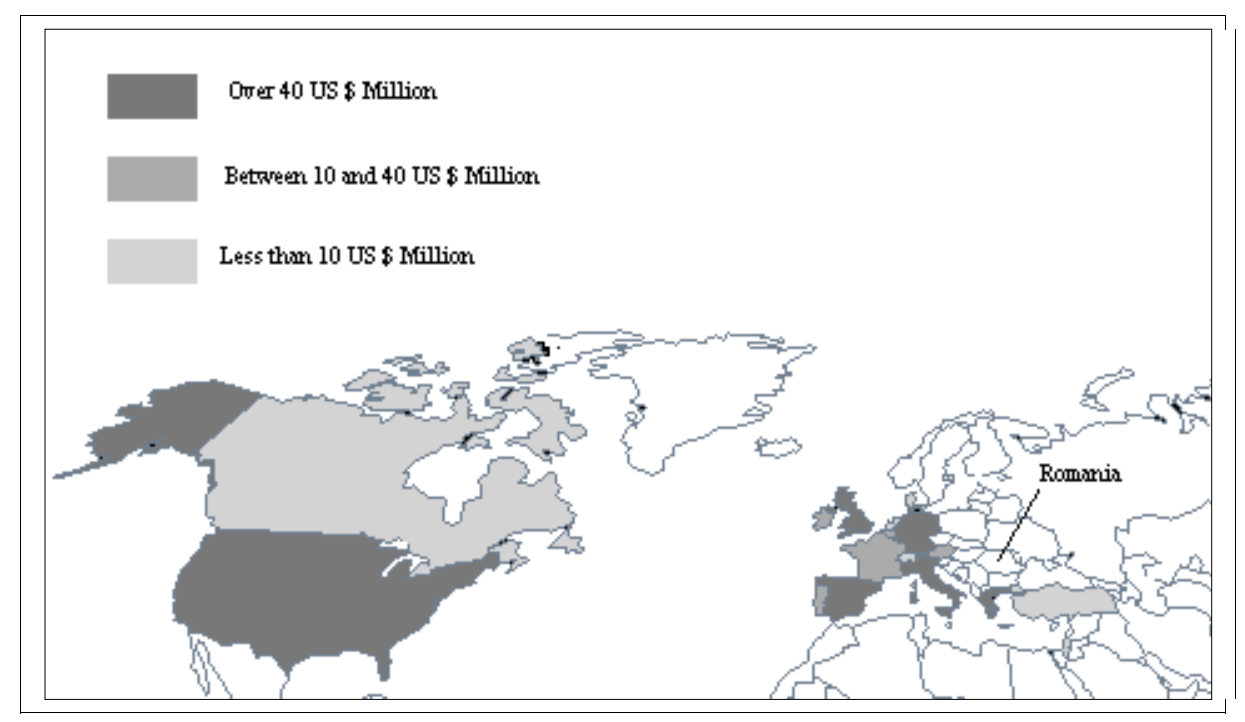

Note: Remittance flows (average per semester) to Romania from 2005 to 2009.

Figure edited with Philcarto. Source: National Bank of Romania.

Data constraints are relatively strong in the literature. Almost all papers do not identify the the remittance-sending country. The first studies using bilateral data work with a tiny number of observations (Lianos, 1997; Straubhaar, 1986). ${ }^{10}$ Two recent papers, done independently and concurrently to ours, work with larger samples. Lueth and Ruiz-Arranz (2008) use a sample of 11 receiving countries. Each one has recorded flows from about 16 sending countries and different period of time. The authors find evidence that remittances follow a gravity type pattern: bilateral remittances increase with the sending and receiving countries' GDP and decrease with geographic distance (see below). Schiopu and Siegfried (2006) work with a sample of 21 European sending countries and 7 European receiving countries, over the period 2000-2005. The authors find evidence for altruism on the belief that bilateral remittances increase with the difference between sending and receiving countries' GDPs. We may wonder however whether such a difference is a good indicator to capture altruism motives (see Rapoport and Docquier, 2006).

\footnotetext{
${ }^{10}$ Lianos (1997) works on Greek inflows of remittances: 31 observations from Germany (1961-1991), 11 from Belgium (1981-1991) and 12 from Sweden (1980-1991). Straubhaar (1986) uses a time series of 19 remittance flows from Germany to Turkey (1963-1982).
} 
Related to international organisms, such as the IMF (Lueth and Ruiz-Arranz, 2008) and the European Commission (Schiopu and Siegfried, 2006), both papers have built large data sets, which is a valuable contribution. ${ }^{11}$ Using a large sample of observations introduces more variability on remittance patterns and allows for more general results, but faces a potential drawback. Remittances are recorded in very different ways among receiving countries, due to a lack of international harmonization in the data collection. This heterogeneity undermines the scope of the results. Working on one receiving country (here Romania) and various remitters reduces the size of the sample but avoids the previous drawback. Remittances are recorded in a more homogeneous way.

\section{A specification of bilateral remittances}

Having introduced our data set on bilateral aggregate remittances, we now investigate a broader issue: the determinants of bilateral remittance flows. According to the theoretical and empirical literature, the main determinants of aggregate remittances are related to (a) economic size, (b) financial environment and (c) labour market (see Appendix 1 for a short review of the literature). Our basic regression accounts for these factors. Recall that in our sample the receiving country is always Romania. Thus, we discard receiving country-variable controls. These variables only have time-series variation, captured by allowing for time specific effects in remittances:

$$
\begin{aligned}
\ln \left(\text { Remittances }_{\mathrm{it}_{\mathrm{it}}=\quad}\right. & \beta_{0}+\beta_{1} \ln \left(\text { Distance }_{\mathrm{i}}+\beta_{2} \ln (\text { GDP })_{\mathrm{it}}+\beta_{3} \ln \left(\text { ExChange }_{\mathrm{it}}\right.\right. \\
& +\beta_{4} \ln \left(\text { Unemploy }_{\mathrm{it}}+\text { RegDum }_{\mathrm{i}}+\text { YearDum }_{\mathrm{t}}+\varepsilon_{\mathrm{it}},\right.
\end{aligned}
$$

where $i$ and $t$ indicate the remittance-sending country and time, respectively. The dependant variable (Remittances) $)_{\text {it }}$ is the value of bilateral remittance flows from the sending country $i$ to Romania from the first quarter of 2005 to the third quarter of 2009. The explanatory variables

\footnotetext{
${ }^{11}$ For instance, Frankel (2009) uses the Lueth and Ruiz-Arranz's sample to study the countercyclical effects of remittances.
} 
are defined as follows: $(\text { Distance })_{\mathrm{i}}$ is the bilateral distance between $i$ and Romania; $(G D P)_{\mathrm{i}}$ is the quarterly Gross Domestic Product of country $i ;(\text { ExChange })_{\mathrm{i}}$ denotes the quarterly nominal exchange rate of country $i$ facing the Romanian Lei. (Unemploy) $)_{\mathrm{i}}$ is the quarterly unemployment rate of country i. (RegDum $)_{\mathrm{i}}$ and $(\text { YearDum })_{\mathrm{t}}$ are regional and year dummies respectively. ${ }^{12} \varepsilon_{\text {it }}$ represents the usual error term capturing unobserved factors and mismeasurements of the remittance level. We use logs on both sides of the equation to reduce the potential skewness of the distribution and to interpret the estimates in elasticity terms. The coefficient of interest to us is $\beta_{1}$, the elasticity of remittances to distance.

Details about the definition and source of regressors are provided in Appendix 2. In Appendix 3, we provide some summary statistics for the variables.

\section{Estimates of bilateral determinants of remittances}

Table 2 reports the estimation of equation (1). We use Ordinary Least Squares (OLS) in columns (1) to (3) and panel data estimators from column (4) to (6).

\footnotetext{
${ }^{12}$ Regional dummies are defined in Appendix 2 (Table A.1). We control for country specific effects by using panel data techniques (see below). We have also introduced quarter dummies into the regressions but their estimates were statistically insignificant.
} 
Table 2. Bilateral remittances determinants

\begin{tabular}{|c|c|c|c|c|c|c|}
\hline Column: & (1) & (2) & (3) & (4) & (5) & (6) \\
\hline Dependent variable $^{\mathrm{a}}$ : & $\ln (\mathrm{R})$ & $\ln (\mathrm{R})$ & $\ln (\mathrm{R})$ & $\ln (\mathrm{R})$ & $\ln (\mathrm{R})$ & $\ln (\mathrm{R})$ \\
\hline Estimation method: & OLS & OLS & OLS & $\mathrm{RE}$ & $\mathrm{FE}$ & Mundlak RE \\
\hline $\ln (G D P)_{\mathrm{i}}$ & $\begin{array}{c}0.716^{* * *} \\
(15.20)\end{array}$ & $\begin{array}{c}0.727 * * * \\
(16.13)\end{array}$ & $\begin{array}{c}0.651 * * * \\
(13.25)\end{array}$ & $\begin{array}{c}0.587 * * * \\
(5.34)\end{array}$ & $\begin{array}{l}0.661 \\
(1.60)\end{array}$ & $\begin{array}{l}0.678^{*} \\
(1.66)\end{array}$ \\
\hline $\ln (\text { ExChange })_{\text {ir }}$ & $\begin{array}{c}-0.750^{* * *} \\
(3.97)\end{array}$ & $\begin{array}{c}-0.689 * * * \\
(3.85)\end{array}$ & $\begin{array}{c}-0.716^{* * *} \\
(4.05)\end{array}$ & $\begin{array}{c}-1.017^{* *} \\
(2.31)\end{array}$ & $\begin{array}{c}-2.072^{* *} \\
(2.50)\end{array}$ & $\begin{array}{c}-2.108^{* *} \\
(2.46)\end{array}$ \\
\hline $\ln \left(\right.$ Unemployment $_{i}$ & $\begin{array}{c}-0.480^{* *} \\
(2.24)\end{array}$ & $\begin{array}{c}-0.587 * * * \\
(2.74)\end{array}$ & $\begin{array}{l}-0.364 * \\
(1.65)\end{array}$ & $\begin{array}{l}-0.742 * \\
(1.92)\end{array}$ & $\begin{array}{c}-0.833^{* *} \\
(2.43)\end{array}$ & $\begin{array}{c}-0.820^{* *} \\
(2.34)\end{array}$ \\
\hline $\ln (\text { Distance })_{\mathrm{ir}}$ & & $\begin{array}{c}0.496^{* * *} \\
(2.66)\end{array}$ & $\begin{array}{c}0.484 * * * \\
(2.61)\end{array}$ & $\begin{array}{c}0.736^{* *} \\
(2.13)\end{array}$ & (dropped) & $\begin{array}{c}0.796^{* *} \\
(2.15)\end{array}$ \\
\hline$(\text { Region } 2 \text { dummy })_{\mathrm{i}}$ & $\begin{array}{c}0.589^{* * *} \\
(2.92)\end{array}$ & $\begin{array}{c}1.374 * * * \\
(4.06)\end{array}$ & & $\begin{array}{l}1.416 \\
(1.59)\end{array}$ & (dropped) & $\begin{array}{c}1.782 \\
(1.64)\end{array}$ \\
\hline$(\text { Region } 3 \text { dummy })_{\mathrm{i}}$ & $\begin{array}{c}2.356 * * * \\
(8.64)\end{array}$ & $\begin{array}{c}3.291 * * * \\
(8.53)\end{array}$ & $\begin{array}{c}1.782 * * * \\
(10.88)\end{array}$ & $\begin{array}{c}3.284 * * * \\
(3.50)\end{array}$ & (dropped) & $\begin{array}{c}3.709 * * * \\
(3.03)\end{array}$ \\
\hline 2006 dummy & $\begin{array}{c}0.423 * * * \\
(3.08)\end{array}$ & $\begin{array}{c}0.375^{* * *} \\
(2.96)\end{array}$ & $\begin{array}{c}0.392 * * * \\
(2.79)\end{array}$ & $\begin{array}{c}0.271 * * * \\
(3.52)\end{array}$ & $\begin{array}{c}0.256^{* * *} \\
(2.88)\end{array}$ & $\begin{array}{c}0.264 * * * \\
(3.18)\end{array}$ \\
\hline 2007 dummy & $\begin{array}{c}0.617^{* * * *} \\
(4.41)\end{array}$ & $\begin{array}{c}0.578^{* * * *} \\
(4.24)\end{array}$ & $\begin{array}{c}0.624 * * * \\
(4.39)\end{array}$ & $\begin{array}{c}0.461 * * * \\
(4.79)\end{array}$ & $\begin{array}{l}0.346^{* *} \\
(2.12)\end{array}$ & $\begin{array}{l}0.348^{* *} \\
(2.14)\end{array}$ \\
\hline 2008 dummy & $\begin{array}{l}-0.282 \\
(1.60)\end{array}$ & $\begin{array}{c}-0.290^{*} \\
(1.72)\end{array}$ & $\begin{array}{l}-0.181 \\
(0.97)\end{array}$ & $\begin{array}{c}-0.258^{* *} \\
(2.12)\end{array}$ & $\begin{array}{l}-0.392 * \\
(1.83)\end{array}$ & $\begin{array}{l}-0.403^{*} \\
(1.83)\end{array}$ \\
\hline 2009 dummy & $\begin{array}{c}-1.072 * * * \\
(4.34)\end{array}$ & $\begin{array}{c}-1.058 * * * \\
(4.36)\end{array}$ & $\begin{array}{c}-1.020^{* * * *} \\
(3.89)\end{array}$ & $\begin{array}{c}-0.961 * * * \\
(4.96)\end{array}$ & $\begin{array}{c}-0.986 * * * \\
(4.77)\end{array}$ & $\begin{array}{c}-0.997 * * * \\
(4.71)\end{array}$ \\
\hline $\begin{array}{l}\text { Obs. Nb. } \\
\text { Adj. } \mathrm{R}^{2}\end{array}$ & $\begin{array}{l}309 \\
0.62\end{array}$ & $\begin{array}{l}309 \\
0.63\end{array}$ & $\begin{array}{l}271 \\
0.61\end{array}$ & $\begin{array}{c}309 \\
-\end{array}$ & $\begin{array}{c}309 \\
-\end{array}$ & $\begin{array}{c}309 \\
-\end{array}$ \\
\hline $\begin{array}{l}\text { Hausman Test } \\
\text { Chi-2;d.1.; prob. }\end{array}$ & & & & & $4.87 ; 7 ; 0.67$ & \\
\hline
\end{tabular}

Notes: ${ }^{a}$ dependent variable: $\mathrm{R}$ means Remittances. Robust t statistics are in parentheses with *significant at $10 \%$ level; **significant at 5\% level; ***significant at $1 \%$ level. Constant and means of the time-varying variables are not reported. In column (3), we have dropped the North American countries from the sample.

We first comment on the cross section estimates. In columns (1) to (3), the adjusted Rsquared shows that our regressors explain about $60 \%$ of the variation in log of bilateral remittances. We first estimate equation (1), without the distance variable (col. 1). As expected, the economic size variable exhibits a positive effect on remittances. Holding other factors constant, a $1 \%$ increase in sending country GDP increases remittances by about $0.7 \%$ on average. In addition, we find a significant negative impact of the bilateral exchange rate. It suggests that an appreciation of the sending's currency vis-à-vis the Lei yields a substitution effect: migrants remit less, while keeping unchanged the purchasing power of the amount 
transferred. ${ }^{13}$ Moreover, we find a negative estimate of the unemployment rate. This is expected since an unemployment rise increases macroeconomic instability, causes significant loss of income and reduces the migrant's probability to be employed. The results on the regional dummies are worth mentioning. They establish a clear and statistically significant ranking: both European regions remit more that North American countries (the base group). But, within Europe, region 3 (i.e. Cyprus, Greece, Ireland, Israel, Italy, Portugal, Spain or Turkey) tends to remit more than region 2 (i.e. Austria, Belgium, Denmark, France, Germany, the Netherlands, Switzerland or the United Kingdom). ${ }^{14}$ Estimated coefficients of year dummies also reveal some interesting patterns. Compared to 2005 (the base year), we observe a significant increase in remittances in 2006 and 2007, no difference in 2008 and a decrease in 2009. This slowdown could be the result of the actual global financial crisis, a phenomenon acknowledged by Ratha and Xu (2008) in developing countries.

In column (2), we investigate the impact of distance on remittances and estimate equation (1). We find a statistically and economically significant positive effect of distance on remittances. Ceteris paribus, a $1 \%$ increase in distance to Romania leads to a $0.5 \%$ increase in bilateral remittances on average.

This result conflicts with the negative elasticity found in Lueth and Ruiz-Arranz (2008) and Frankel (2009). They interpret their result as a transfer cost effect. However, this interpretation is puzzling. The cost of transferring money appears unrelated to geographic distance. As an illustration, consider a US immigrant who wants to remit US \$200 from the USA abroad. This transfer will cost US \$17 to Colombia for a capital-to-capital distance of $3845 \mathrm{kms}$; US \$3 to Mexico, for a roughly similar distance (3038 kms), and US \$4 to Philippines for a much larger distance (13,794 kms). Ratha and Shaw (2007) also find evidence of asymmetric bilateral transfer costs: the cost of remitting US \$200 from a

\footnotetext{
${ }^{13}$ See Appendix 1 for a discussion of the potential income effect of the bilateral exchange rate.

${ }^{14}$ The Wald statistic of the difference between the European regions 2 and 3 is 117.29, with a p-value lower than 0.01 .
} 
developed country to a developing country is significantly much lower than in the opposite direction. $^{15}$

We document instead a positive distance elasticity of remittances but this result is not strictly comparable to Lueth and Ruiz-Arranz (2008) and Frankel (2009). The time span and the country coverage of their sample are quite different from ours (see above). This difference may drive the reverse result. Beyond this, how can we interpret our positive distance effect? One possible interpretation is related to the loan repayment hypothesis which has been documented so far using household surveys. The costs of emigration increase with distance (Mayda, 2009). Thus, a larger distance might imply a larger family loan to finance the move and then larger remittances to repay back the loan. A second interpretation is related to the type of data we observe. As previously stated, we mainly observe official remittances. Thus, if short-distance migrants return home more frequently, they have more opportunities to remit through informal channels, i.e. to make transfers in-kind or to carry themselves the money. As a result, this may lead to a sample selection bias: remittances increase with geographic distance as long as remote migrants remit in a more formal way than close ones.

Before investigating this issue, it is worth mentioning that the difference between the European regions and North America increases by controlling for the effect of distance. This might be explained by the relative remoteness of North American countries compared to Europe for Romanian emigrants. In order to see if the distance effect is driven by the most remote destinations, we drop the USA and Canada from the sample. However, as shown in column (3), the distance elasticity remains positive, highly significant $(\mathrm{p}<0.01)$ and with the same magnitude than in column (2).

In columns (4) to (6), we use panel data estimators. They allow us to exploit the time series dimension of the data and to control for sending country specific effects (beyond the regional

\footnotetext{
15 Moreover, Ratha and Shaw (2007) document higher transfer costs between developing countries. Thus, the costs of transferring money seem more related to the lack of financial development in the labour-sending country (Freund and Spatafora, 2008), than to the geographic distance.
} 
characteristics). This is all the more important since the distance effect might be driven by country characteristics that we cannot observe, such as the opportunity to remit through informal channels. This opportunity may be different from one sending-country to another: e.g. travelling to Romania to carry back the money is more or less expensive and easy across countries. Travel costs depend on distance but also on travel time and transportation infrastructures. Omission to control for these factors may lead to the above mentioned sample selection bias.

The properties of the panel data estimators may depend significantly on whether the sending country effects are specified as random variables or as fixed parameters. As a first approximation, we may assume that the sending country specific effects are uncorrelated with the explanatory variables. The appropriate specification is thus a random effects (RE) model, estimated with the generalized least squares. The estimates are reported in column (4) of Table 2. The distance elasticity remains positive and significant, while its magnitude is larger than using cross section estimates (col. 2). However, the possibility that the sending country effects are correlated with some explanatory variables is so prevalent that it could make little sense to rule out such correlation a priori. In this case, the estimators are generally inconsistent. In contrast, the fixed effects estimator (FE) allows for arbitrary correlation between the sending country effects and the explanatory variables in any time period. The FE estimates are depicted in column (5) of Table 2.

In order to assess the appropriateness of fixed effects and random effects estimation, we implement a Hausman test. The Hausman test, presented at the bottom of column (5), compares the estimable coefficients of the time-varying regressors. The test statistic is quite low which suggests that the country sending effects are uncorrelated with the other variables in the model. Thus, between the two panel data estimators considered, the RE model appears to be more appropriate. Moreover, a caveat of the FE estimator is its inability to estimate the coefficient of our variable of interest: the geographic distance, which is time-invariant. To 
alleviate this problem we consider a particular random effects model: the Mundlak's (1978) approach to estimating panel data. The Mundlak's aproach posits that the sending country specific effect can be projected upon the group means of the time-varying variables. As a consequence, adding the means of the time-varying variables (i.e. GDP, exchange rate and uemployment) to the equation picks up the correlation between the country effects and the explanatory variables (see Wooldridge, 2002). The results are reported in column (6) of Table 2. As expected, the Mundlak RE model gives fairly similar estimates of the time varying variables compared to FE (col. 5). An attractive feature of this model is that it gives an estimate of time-invariant variables. Thus, it confirms the positive distance elasticity of remittances.

In summary, the cross section and panel estimates reveal a positive and significant effect of distance. This effect does not seem to be driven by sending country specific characteristics. We find instead that the panel estimates (col. 4 and 6) of distance are larger in magnitude than the cross section estimates (col. 2). However, due to the magnitude of the standard errors, there is not much statistically significant difference between the cross and the panel estimates of distance.

In Table 3, we account for potential non linear effects of distance on remittances. Estimation in column (1) replaces distance in logarithmic form with distance as a natural number and the square of distance. Estimates of both variables are statistically significant. This estimated equation implies that distance has a diminishing effect on remittances. This result holds when dropping North American countries from the sample (col. 2). In column (3), we allow for different slopes of distance. Thus we recast our model. We add two interactions between distance (in level) and both European regions and keep distance and the regional dummies separately. How do we interpret the coefficients on the distance variables? The estimated distance semi-elasticity for North American countries is negative $-1.172(\mathrm{p}<0.01)$. For region 2 , the distance elasticity is positive $(-1.172+1.173=0.001)$, as for region $3(-$ 
$1.172+1.190=0.018)$. Differences of European regions with North America are not economically large but statistically significant and positive. These results confirm that the distance effect is highly non-linear: the positive effect of distance on remittances appears to be driven by the regions 2 and 3 .

Table 3. Distance

\begin{tabular}{|l|c|c|c|}
\hline Column: & $(1)$ & $(2)$ & $(3)$ \\
\hline Dependent variable $^{\mathrm{a}}:$ & $\ln (\mathrm{R})$ & $\ln (\mathrm{R})$ & $\ln (\mathrm{R})$ \\
\hline Estimation method: & OLS & OLS & OLS \\
\hline (..) & $(\ldots)$ & $(\ldots)$ & $(\ldots)$ \\
Distance & $0.360^{* * *}$ & $0.359^{* * *}$ & $-1.172^{* * *}$ \\
& $(7.27)$ & $(6.00)$ & $(4.95)$ \\
Distance & $-0.010^{* * *}$ & $-0.010^{* * *}$ & \\
& $(7.59)$ & $(6.17)$ & \\
Region2Xdistance & & & $1.173^{* * *}$ \\
& & & $(4.98)$ \\
Region3Xdistance & & & $1.190^{* * *}$ \\
& & & $(4.99)$ \\
\hline Regional dummies & yes & yes & yes \\
Years dummies & yes & yes & yes \\
Obs. Nb. & 309 & 271 & 309 \\
Adj. $\mathrm{R}^{2}$ & 0.69 & 0.66 & 0.64 \\
\hline
\end{tabular}

Notes: ${ }^{\mathrm{a}} \mathrm{R}$ means Remittances. Robust $\mathrm{t}$ statistics are in parentheses with ***significant at $1 \%$ level. Estimates of the intercept and the other covariates are not reported. For presentation purposes the distance variable has been rescaled to units of $100 \mathrm{kms}$. In column (2), we have dropped the North American countries from the sample.

\section{Conclusion}

Recent literature addresses a relevant policy question: what causes different developing countries to receive different levels of remittances? Using a new data set on bilateral remittance flows we further explore this question. We wonder whether bilateral geographic distance to the remittance-sending country matters. Over the period 2005-2009, we find that long-distance migrants tend to remit more than short-distance migrants. This result holds using cross section and panel data estimators. But, this effect tends to be at diminishing rates and specific to some groups of countries. Moreover, we confirm the significant effect of economic size, as well as financial and labour market factors. Finally, using the time series 
dimension of data, from 2005 to 2009 , we document a negative impact of the recent financial crises on remittances to Romania.

\section{References}

Adams, R.H. (2009) The Determinants of international remittances in developing countries. World Development, 37(1), pp. 93-103.

Borjas, G. (1999) The economic analysis of immigration, in: Ashenfelter O. and D. Card (eds) Handbook of Labor Economics, 3(A), (North-Holland: Elsevier), pp. 1697-1760.

Docquier, F. and Rapoport, H. (2009) The economics of the brain drain. Mimeo, IRES.

Docquier, F., Lowell, B.L. and Marfouk, A. (2009) A gendered assessment of highly skilled emigration. Population and Development Review, 35(2), pp. 297-322.

El-Sakka, M. and McNabb R. (1999) The macroeconomic determinants of emigrant remittances. World Development, 27(8), pp. 1493-1502.

Elbadawi, I. and Rocha, R. (1992) Determinants of expatriate workers' remittances in North America and Europe. Policy research working paper, World Bank.

Frankel, J. (2009) Are bilateral remittances countercyclical?, NBER working paper, 15149.

Freund, C. and Spatafora, N. (2008) Remittances, transaction costs, and informality. Journal of Development Economics, 86(2), pp. 356-366.

Ilahi, N. and Jafarey, S. (1999) Guestworker migration, remittances and the extended family: evidence from Pakistan. Journal of Development Economics, 58(2), pp. 485-512.

Johnson, G. E. and Whitelaw, W. E. (1974) Urban-rural income transfers in Kenya: An estimated-remittances function. Economic Development and Cultural Change, 22(3), pp. $473-479$.

Lianos, T. (1997) Factors determining migrant remittances: the case of Greece. International Migration Review, 31(1), pp. 72-87.

Lucas, R.E.B. and Stark O. (1985), Motivations to remit: evidence from Botswana. Journal of Political Economy, 93(5), pp. 901-918.

Lueth, E. and Ruiz-Arranz, M (2008) Determinants of bilateral remittance flows. B.E. Journal of Macroeconomics, 8(1), Topics, Article 26.

Mayda, A.M. (2009) International migration: A panel data analysis of the determinants of bilateral flows. Journal of Population Economics (forthcoming).

OECD (2006) International Migration Outlook. SOPEMI. 
Mundlak, Y. (1978) On the pooling of time series and cross section data, Econometrica, 46(1), pp. 69-85.

Poirine, B. (1997) A theory of remittances as an implicit family loan arrangement. World Development, 25(4), pp. 589-611.

Rapoport, H. and Docquier, F. (2006) The economics of migrants' remittances, in: MercierYthier J. and S. Kolm (eds), Handbook on the economics of giving, altruism and reciprocity, (North-Holland: Elsevier), pp. 1135-1198.

Ratha, D. (2005) Workers' remittances: an important and stable source of external development finance, in: S.M. Maimbo and D. Ratha (eds), Remittances: development impact and future prospects, (Washington: World Bank), pp. 19-52.

Ratha, D. and Shaw, W. (2007) South-south migration and remittances (Washington: World Bank).

Ratha, D. and Xu, Z. (2008) Migration and remittances factbook (Washington: World Bank).

Schiopu, I. and Siegfried N. (2006) Determinants of workers' remittances-evidence from the European Neighbouring Region, Working Paper Series 688, European Central Bank.

Stark, O. and Lucas, R.E.B. (1988) Migration, remittances, and the family. Economic Development and Cultural Change, 36(3), pp. 465-481.

Straubhaar, T. (1986) The determinants of workers' remittances: The case of Turkey. Review of World Economics, 122(4), pp. 728-740.

Wooldridge, J. (2002), Econometric Analysis of Cross Section and Panel Data, (Cambridge: MIT Press).

World Bank (2003). Romania poverty assessment (Washington: World Bank). 


\section{Appendix 1. Control variables}

According to the literature, the main determinants of aggregate remittances are related to the following factors: (a) economic size, (b) financial environment and (c) labour market. We briefly review the literature on their impact. Then, we discuss the expected effects of regional dummies.

\section{a. Economic size:}

The empirical literature is unanimous on the effect of economic size. Remittances are an increasing function of the aggregate income of the sending country $i$, proxied by GDP (Elbadawi and Rocha, 1992; Lianos, 1997). This is consistent with the patterns displayed using simple descriptive statistics. In 2007, the United States and Western Europe account for almost two-third of remittance flows to developing countries (Ratha and $\mathrm{Xu}, 2008$ ).

\section{b. Financial environment:}

Financial variables, such as exchange rates, are considered as important determinants of remittances (Adams, 2009; El-Sakka and McNabb, 1999; Elbadawi and Rocha, 1992; Lianos, 1997). Due to the bilateral nature of our sample, we consider the effect of the bilateral exchange rate. A variation of (ExChange) $)_{\mathrm{i}}$ affects the purchasing power of remittances and leads to an ambiguous effect. Consider an appreciation of the sending's currency vis-à-vis the Lei. We get to two opposite effects: (1) an income effect: migrants remit more to benefit from an increasing purchasing power; (2) a substitution effect: migrants remit less, while keeping unchanged the purchasing power of the amount transferred.

\section{c. Labour market:}

The literature documents unambiguously that an increase in the unemployment of the sending country $i$ negatively impacts on the volume of remittances. Three complementary explanations are at hand. First, a rise in unemployment causes significant losses of income which reduce remittances. Second, this rise increases the migrant's uncertainty about future incomes, and may incite migrants to decrease their remittances in anticipation. Finally, a high 
rate of unemployment reduces the migrant's probability to be employed and therefore the probability to remit. In fact, in all the OECD countries, except Italy and Greece, unemployment affects immigrants especially (OECD, 2006).

\section{d. Regional dummies:}

We introduce regional dummies to control for group characteristics. Using the OECD (2006) outlook on international migration, we identify three relatively homogeneous groups of countries. Among others, they present similarities in the way they deal with the international transit of persons.

Region 1 is the base group against which comparisons are made. It includes Canada and the United States. They are immigration countries long ago and tend to attract and keep in priority skilled migrants (OECD, 2006: 194). Their structure of immigration differs from European countries (Docquier et al., 2009). They are also located on a different continent.

As acknowledged by the OECD outlook (2006: 80), we split the European countries into two distinct groups (region 2 and region 3). Region 2 regroups the following Western European countries: Austria, Belgium, Denmark, France, Germany, the Netherlands, Switzerland and the United Kingdom. They promoted a mass immigration since the post-war period until the seventies. Then, they adopted more restrictive immigration policies. In contrast, region 3 presents a different pattern of migration. This group involves Cyprus, Greece, Ireland, Israel, Italy, Portugal, Spain and Turkey. Broadly speaking, from the postwar period until the seventies, these countries were labour-sending countries. Then, they became more developed and after the adoption of restrictive policies in the older immigration countries, they became labour-receiving countries. Moreover, most of these countries are also the ones where language is very similar to Romanian. This eases the integration of the Romanian immigrants. ${ }^{16}$

\footnotetext{
${ }^{16}$ We are grateful to one referee for this comment.
} 
We argue that among others the way these groups deal with international migration may affect remittances. Restrictive immigration policies aim to prevent irregular immigration.

Since illegal Romanian migration to Europe, as a whole, seems easier than to North America, we expect a higher stock of illegal migrants in Europe and thus larger remittances (given that illegal migrants transfer money trough legal means).

\section{Appendix 2. Data construction}

Table A.1. Data and variable definitions

\begin{tabular}{|c|c|}
\hline Variables & Description \\
\hline Bilateral remittances & $\begin{array}{l}\text { Come from the National Bank of Romania. Quarterly frequency. } \\
\text { Converted into current USD using a quarterly exchange rate from } \\
\text { International Financial Statistics (IMF). }\end{array}$ \\
\hline Bilateral distance & $\begin{array}{l}\text { Computed as the distance in kilometres between the largest cities of the } \\
\text { two countries. Source: CEPII. }\end{array}$ \\
\hline GDP & Gross Domestic Product. Quarterly frequency. Source: OECD. \\
\hline Bilateral exchange rate & $\begin{array}{l}\text { Measured in Romanian Lei per unit of foreign currency. Quarterly } \\
\text { frequency. Source: International Financial Statistics. }\end{array}$ \\
\hline Unemployment rate & $\begin{array}{l}\text { Extracted from OECD Stat Web Browse, except for Turkey (IMF). } \\
\text { Quarterly frequency. }\end{array}$ \\
\hline Region 1 & $\begin{array}{l}=1 \text { if the remittance-sending country is Canada and the United States, } \\
\text { and } 0 \text { otherwise. }\end{array}$ \\
\hline Region 2 & $\begin{array}{l}=1 \text { if the remittance-sending country is Austria, Belgium, Denmark, } \\
\text { France, Germany, the Netherlands, Switzerland or the United } \\
\text { Kingdom, and } 0 \text { otherwise. }\end{array}$ \\
\hline Region 3 & $\begin{array}{l}=1 \text { if the remittance-sending country is Cyprus, Greece, Ireland, Israel, } \\
\text { Italy, Portugal, Spain or Turkey, and } 0 \text { otherwise. }\end{array}$ \\
\hline
\end{tabular}

\section{Appendix 3. Summary statistics}

Table A.2. Summary statistics of the variables

\begin{tabular}{|l|c|c|c|c|}
\hline \multicolumn{1}{|c|}{ Variables } & Mean & Standard deviation & Min & Max \\
\hline $\ln$ (Bilateral Remittances) & 17.28 & 1.36 & 14.78 & 20.45 \\
$\ln$ (Bilateral Distance) & 7.58 & 0.72 & 6.09 & 8.96 \\
$\ln$ (GDP) & 27.50 & 1.20 & 25.77 & 30.31 \\
$\ln$ (Bilateral Exchange Rate) & 0.31 & -0.71 & 2.11 & 1.61 \\
$\ln$ (Unemployment Rate) & 1.86 & 0.31 & 1.16 & 2.47 \\
Region 2 & 0.45 & 0.50 & 0 & 1 \\
Region 3 & 0.40 & 0.49 & 0 & 1 \\
\hline
\end{tabular}

Note: 309 observations. 